\title{
ON THE POSITION OF PLATYGARPUM HUMB. ET BONPL., HENRIQUEZIA SPRUCE EX BTH. AND GLEASONIA STANDL.
}

\author{
C. E. B. BREMEKAMP \\ (Botanical Museum, Utrecht) \\ (received February 15th, 1957)
}

\section{INTRODUCTION}

Some time ago the "Instituto Agronómico do Norte, Belem, Pará, Brazzl" sent me a set of specimens for identification among which I detected a new species of Henriquezia Spruce ex Bth. This discovery induced me to study once more and now in somewhat more detail the relation between this genus and the nearly related Platycarpum Humb. et Bonpl. and the position these two genera occupy with regard to the habitually rather similar Gleasonia Standl., a subject to which I had already paid some attention at an earlier occasion, and on which I had reported in a note which is to be found at the base of p. 16 of my work on "the African Species of Oldenlandia L sensu Hiern et K. Schumann" in Verh. Kon. Ned. Akad. v. Wetensch., Sect. 2, 48, no 4, 1952. By the good office of Dr Bassett Maguire I received on loan from the New York Botanical Garden the rich materials by which, as a result of the Botanical Garden's recent expeditions to Tropical America, these genera are represented in its herbarium, and during a recent visit to England I could study also the valuable collections in the herbarium of the Royal Botanic Gardens, Kew. In the course of these studies I discovered among the Platycarpum specimens too a new species. Descriptions of the latter and of my new Henriquezia will be found further on in this paper. They are, however, but of secondary importance; the main object of this study is to ascertain as precisely as possible the taxonomical position of these three rather puzzling genera.

In the note on p. 16 of my work on "the African Species of Oldenlandia L sensu Hiern et K. Schumann" I stated that Gleasonia Standl. "on account of the large and flat exalbuminous seeds and also because of the very peculiar structure of the testa is to be referred to the Henriquezieae, a tribe that will have to be removed as a separate family to the Tubiflorae." In support of this opinion I referred to Fig. c, d, $e$ and $f$ of Tab. $V$, which represent the testa of Henriquezia verticillata Spruce ex Bth., of Platycarpum orinocense Humb. et Bonpl. and of two species of Gleasonia, viz. Gl. uaupensis Ducke and Gl. macrocalyx Ducke.

The study of the more abundant and better material that I had now at my disposition has led to a somewhat different standpoint. The differences between Gleasonia and the two other genera appeared to be of far greater taxonomical importance than the points of resem- 
blance, and although this more detailed study did not shake the opinion I had arrived at with regard to the genera Platycarpum and Henriquezia, viz. that they are to be regarded as representatives of a new family Henriqueziaceae, for which on account of its affinity with the Bignoniaceae, Pedaliaceae, Martyniaceae, Thunbergiaceae, Mendonciaceae and Acanthaceae, a position will have to be found in the order Tubiflorae, I now see that the genus Gleasonia can not be regarded as a very near ally, and that it is either to be left in the Rubiaceae, where it occupies, on account of the exalbuminous seeds and the large size of the cotyledons, an anomalous position, or else to be referred to a new family, which however, on account of the structure of flower and fruit and of the presence of colleters on the inside of the stipules, would have to be placed in the near vicinity of the Rubiaceae. This implies, of course, that the points of resemblance between Gleasonia and the genera Platycarpum and Henriquezia, on which I based my former view, are no longer accepted by me as homologies, but that I now regard them as mere analogies.

The change in my opinion with regard to the taxonomical position of Gleasonia is due to a better insight in the characters in which this genus differs from the two other ones and in those in which it resembles them. In order to facilitate a discussion, I will first of all give an enumeration of the differences, as the latter are in this respect of more importance than the points of resemblance.

\section{Comparison Between Gleasonia and the Genera Platycarpum and Henriquezia.}

The principal differences between Gleasonia and the two other genera are: 1) the absence in Gleosonia of the peculiar "glands" that in Platycarpum and Henriquezia are found at the base of the petiole, and which in fact are found nowhere else in the whole kingdom of plants; 2) the presence of colleters or resin glands on the inside of the stipules of Gleasonia, a character which this genus shares with the great majority of the Rubiaceae, and their absence in Platycarpum and Henriquezia; 3) a different structure of the corolla, that of Gleasonia: being actinomorphous with induplicate aestivation of the lobes, that of the two other genera zygomorphous with a longitudinal streak of hairs on the ventral side of the throat and with ascending aestivation (cf. Fig. 1); 4) a different structure of the androecium, which
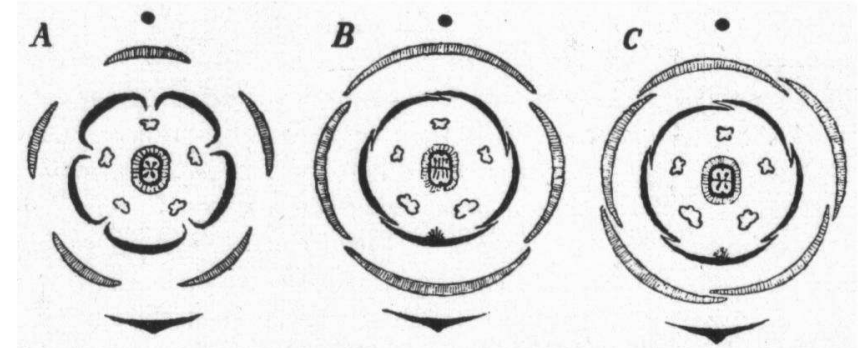

Fig. 1. Floral diagrams of A. Gleasonia duidana, B. Henriquezia perticillata and' C. Platycarpwm orinocense. 
in Gleasonia is subregular, in Platycarpum and Henriquezia distinctly zygomorphous, the filaments being inserted at unequal height, bent at the base and of unequal length; 5) a different arrangement of the ovules (cf. Fig. 2), those of Gleasonia forming in each ovary cell a double row which ascends to about midway the dissepiment, whereas the two to four ovules found in each of the ovary cells of the two other genera are inserted at nearly the same height; and 6) a different development of the capsule, that of Gleasonia (Fig. 9, p. 000) remaining entirely inferior, whereas that of the two other genera becomes either semi-superior (Henriquezia, Fig. 11, p. 000) or even almost completely superior (Platycarpum, Fig. 10, p. 000). Less important points of difference are found in the arrangement of the pollen grains, those of Gleasonia (Fig. 3) remaining united in tetrads, whereas they are set free in the two other genera, and also in their structure, those of Gleasonia always being 3-colpate, those of the other genera (Fig. 4) either 3- or 4- or 5- or 6-colpate, in the number and shape of the seeds, those of Gleasonia being more numerous and more or less swollen and angular, whereas the two to four seeds of the two other genera are flat, and in the structure of the testa, the cells being convex in Gleasonia, and produced into papillae in Henriquezia (Fig. 5) and Platycarpum (Fig. 6). Before proceeding to the points of resemblance, it will be well to discuss these differences, the more important ones as well as the others, in some detail.

The "glands" which in Platycarpum and Henriquezia are seen at the base of the petiole on the side facing outwards, are large glabrous and shiny spots slightly protruding beyond the surrounding tissue; in herbarium material they at once draw the attention by the black colour they assume in drying. Their exact nature is unknown: it is possible that they secrete a sugary fluid, and in that case they would belong to the large class of extra-floral nectaries, but it may also be that they are bacterial nodules; without living material it will probably be difficult to settle this point. Howsoever this may be, these petiolar "glands" certainly are a very characteristic feature of these two genera, the like of which is found nowhere else.

The presence of colleters or resin glands on the inside of the stipules of Gleasonia is a character which this genus shares with the majority of the Rubiaceae. In fact, they are, as was shown by KRAUSE (Ueber harzsecernierende Drüsen an den Nebenblättern von Rubiaceen, in Ber. d. d. bot. Gesellsch. 27: 446-452. 1909), found in all tribes of this family with the exception of the Rubieae (Galieae). Their absence in this tribe might be an argument in favour of the view that the supernumerary leaf-like parts of these plants are no modified stipules, as is now commonly accepted, but that they are true leaves.

According to Krause colleters would be present in the genus. Henriquezia too, but this must be a mistake. Although I did not investigate the species quoted by him, the apparently very rare $H$. nitida. Spruce ex Bth., I studied three other species, viz. H. verticillata Spruce ex Bth., $H$. macrophylla Ducke and $H$. longisepala Brem. v. infra, and in addition several species of Platycarpum, but in none of them I could 
find the slightest trace of these structures. I suppose therefore that the specimen studied by Krause will have been misidentified, and that it belonged in reality to some other genus.

It is noteworthy that although colleters are by no means confined to the Rubiaceae (cf. HANstein in Bot. Ztg 26: 697-713, 720-735, 744-761 and 768-787. 1868), they are in this family of a rather peculiar structure which returns only in the Cunoniaceae, a family that may be distantly related to the Rubiaceae, and in the genus Viola. That the colleters of Gleasonia too are of this type, is certainly a weighty argument in favour of the view that this genus belongs either to the Rubiaceae themselves or else to a new family for which a place will have to be found in the near vicinity of the latter.

That the corolla of Gleasonia is actinomorphous is in itself perhaps not very important, but in connection with the valvate, or more precisely induplicate, aestivation of its lobes it is certainly not easily reconcilable with the view that this genus would be a near ally of Platycarpum and Henriquezia, where the corolla is more or less distinctly zygomorphous with a longitudinal strip of hairs on the ventral side of the throat, and where the aestivation is ascending-imbricate.

The zygomorphism of the corolla would not exclude the genera Platycarpum and Henriquezia from the Rubiaceae, for slightly zygomorphous corollae are in this family certainly not unknown, although they never show a band of hairs on the ventral side of the throat. A slightly unequal length of the filaments is here, as an accompanying feature, not uncommon either. As examples of such a slight zygomorphism of the androecium corresponding to a curvature of the upper part of the corolla, we may refer to the genera Pallasia Klotzsch, Macrocnemum Wedd., Ferdinandusa Pohl and Posoqueria Aubl. This form of zygomorphism, however, is of little importance as it does not obscure the fundamental symmetry of the plan according to which the flower is built. In this respect it is of hardly more value than the zygomorphism of the calyx that is so often met with in genera belonging to this family, and which is due to the development of one of the calyx lobes into a foliaceous appendage, a form of zygomorphism that does not affect the other parts of the flower, and is moreover restricted to a few flowers per inflorescence. The androecium of Platycarpum and Henriquezia, however, shows a fundamentally different form of zygomorphism, which finds its expression in the insertion of the filaments at unequal height and in a curvature of their basal part. Among the genera for which a position in the Rubiaceae has been claimed, the number of those that are provided with a zygomorphous androecium of this kind is very small indeed, and there is in all these instances (e.g. Tammsia Karst., Aitchisonia Hemsl.) good reason to doubt the correctness of their classification; in none of them, moreover, the filaments are bent at their base.

The difference in the arrangement of the ovules is another argument against the view that Gleasonia would be a near ally of Platycarpum and Henriquezia (cf. Fig. 2), but the arrangement itself gives us no indication with regard to the taxonomic position either of Gleasonia or of 
the two other genera, for arrangements similar to that seen in Gleasonia as well as arrangements of the kind observed in Platycarpum and Henriquezia are found in families belonging to very different families and orders.

The capsule of Gleasonia (Fig. 9, p. 364) is of a type for which we might easily find a place within the range of those that are met with

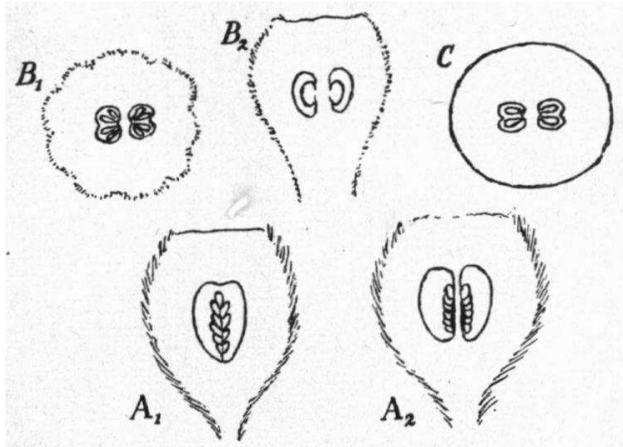

Fig. 2. Ovary of A. Gleasonia duidana, B. Henriquezia longisepala, and C. Platycarpum orinocence. Note the ridge opposite the placenta in the ovary cells of Henriquezia and Platycarpum.

among the Rubiaceae, but the semi-superior or almost completely superior capsules found in Henriquezia (Fig. 11, p. 373) and Platycarpum (Fig. 10, p. 372) are of a more aberrant kind. Nevertheless their deviation from the ordinary inferior type of capsule, although accentuating once more the width of the gap which separates these two genera from Gleasonia, would in itself not be sufficient to exclude these genera from the Rubiaceae, as a similar deviation occurs in the tribe Gaertnerieae, whose position in the family must, on account of its very close resemblance to the Psychotrieae, be regarded as well-established.

The less important differences mentioned at the end of our list, are found in the pollen characters and in number, shape and structure of the seeds.

That the pollen grains of Gleasonia (Fig. 3) remain united in tetrads, is doubtless a somewhat unexpected feature, which sharply differentiates this genus from Platycarpum and Henriquezia, but whose taxonomical importance should not be overrated. It is certainly not a character on account of which the genus would have to be excluded from the Rubiaceae, for pollen grains united in tetrads are not unknown in this family; they are e.g. a general character of the genus Randia (Houst.) L sensu Fagerlind. The uncommonly large size of the individual grains (diam. $70 \mu$ in Gl.uaupensis and $110 \mu$ in Gl.duidana) is in this respect perhaps of somewhat greater importance, as the pollen grains of the Rubiaceae are, on the whole, rather small; even the largest ones that are known so far (they were found in the genera Richardia (Houst.) L. and Palicourea Aubl.) are not so bulky as those of Gleasonia. That the pollen grains of Platycarpum and Henriquezia too are very large, is, of course, a point of resemblance between these 

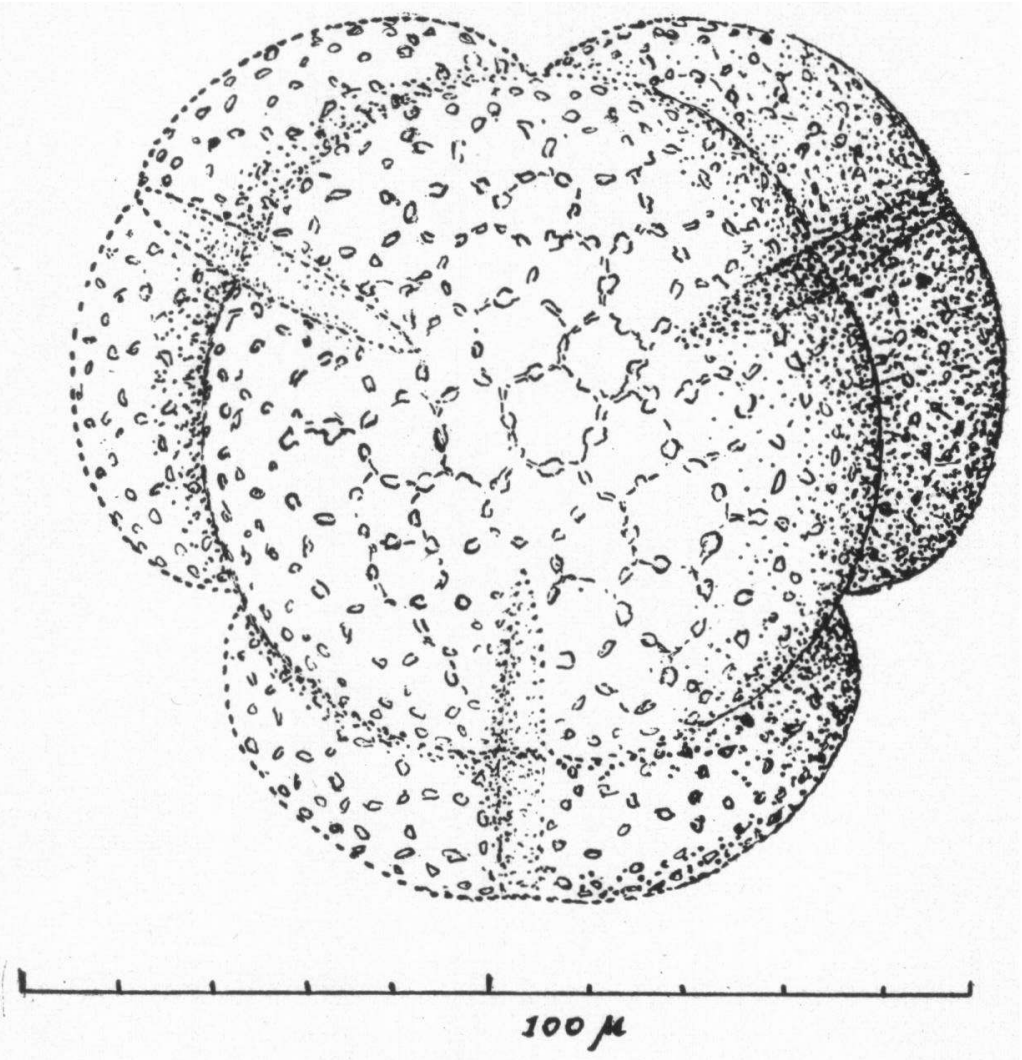

Fig. 3. Pollen tetrad of Gleasonia uaupensis.
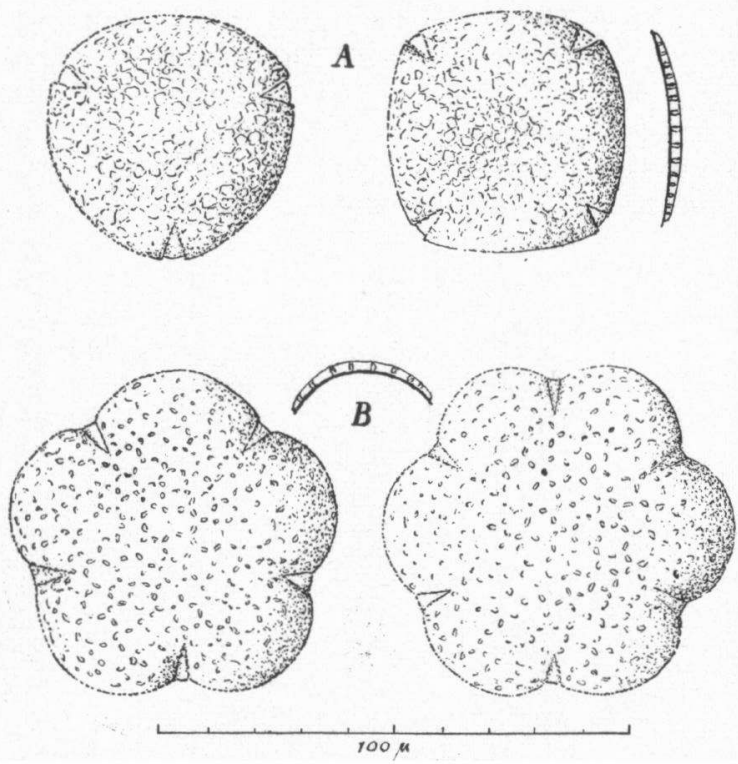

Fig. 4. Pollen grains of A. Platycarpum orinocense, and B. Henriquezia macrophylla. The figure to the right of $A$ and that between the two pollen grains of $B$ are optical sections of the wall. 
genera and Gleasonia, but not one of any importance, as large pollen grains are met with in very different circles of affinity. That the pollen grains of Platycarpum and Henriquezia (Fig. 4) are usually provided with more than three colpae, is on the other hand worth noting, not only because it constitutes a difference with Gleasonia, but also because pollen grains with more than three colpae (or pores) usually characterize groups of a rank far exceeding that of the genus. It is also noteworthy that pollen grains of a very similar type are met with in several of the families of the Tubiflorae with which the genera Platycarpum and Henriquezia show points of resemblance (Bignoniaceae, Pedaliaceae, Mendonciaceae, see on the pollen structures met with in these families my paper on "The Position of the genus Thomandersia Baill." in Rec. d. trav. bot. neerl. 39: 166-175. 1942).

The differences in number and shape of the seeds are not very important either and moreover somewhat obscured by the very striking points of resemblance, viz. the absence of endosperm and the strong development of the cotyledons, points that we will discuss hereafter. The seeds of Gleasonia are more numerous than those of the two other genera, where each of the fruit cells contains but one to four seeds, and they are angular and less strongly compressed.

The difference in the structure of the testa is doubtless of greater importance. The testa cells of Platycarpum (Fig. 5) and Henriquezia

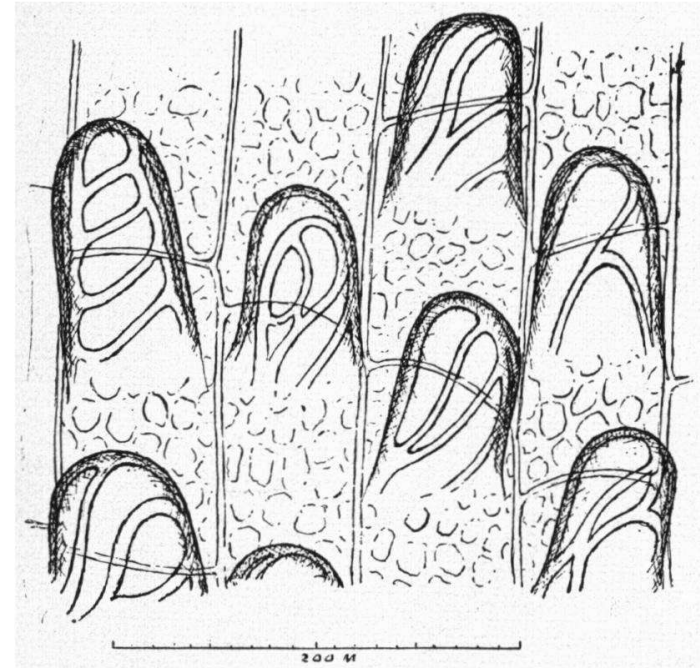

Fig. 5. Testa of Platycarpum orinocense.

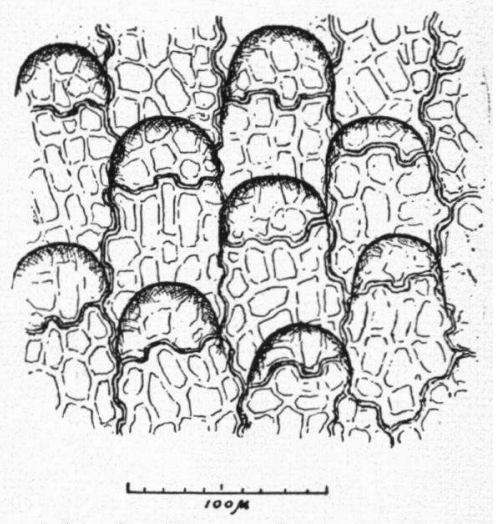

Fig. 6. Testa of Henriquezia verticillata.

(Fig. 6) are drawn out into papillae or short hairs; those of Gleasonia are merely convex. The presence of papillae on the testa was known so far only for Platycarpum, but a renewed study of the testa of Henriquezia verticillata Spruce ex Bth. has led to the conclusion that they are present in this genus too. That they were originally overlooked was due to the circumstance that the seed investigated at that time 
was fully mature; at that stage the outer wall of the testa cells has disappeared; the wall shown in my original figure is the reticulate inner one. For this reason I insert here a new figure in which the outer wall with the papillae is shown. An exactly corresponding structure of the testa is met nowhere in the Rubiaceae, but this would in itself not be enough to exclude these genera, as the variability in the structure of the testa is so large in this family that it is as yet impossible to decide what would fall outside its range.

In the genus Gleasonia the structure of the testa proves to be of an entirely different kind. The two figures given in my earlier communication are unsatisfactory, as the seed of Gl. uaupensis Ducke of which I studied the testa, was not yet fully mature, and as that of $G l$. macrocalyx Ducke was so young that the sclerization of the outer wall had not yet begun. Ripe seeds of $G l$. macrocalyx were this time too not available, so that $I$ am still unable to tell in how far the structure of their testa agrees with that seen in the two other species. The wartlets on the testa, of which one was figured in my earlier publication, are at any rate a feature by which these seeds differ from those of the two other species. Of the latter, Gl. duidana Standl., the species on which the genus was founded, and $G l$. uaupensis, fully mature seeds could now be studied. The testa cells of these two species have a convex outer wall, which proves to be provided with an irregular network of thickenings (Fig. 7), which in fully mature seeds extends

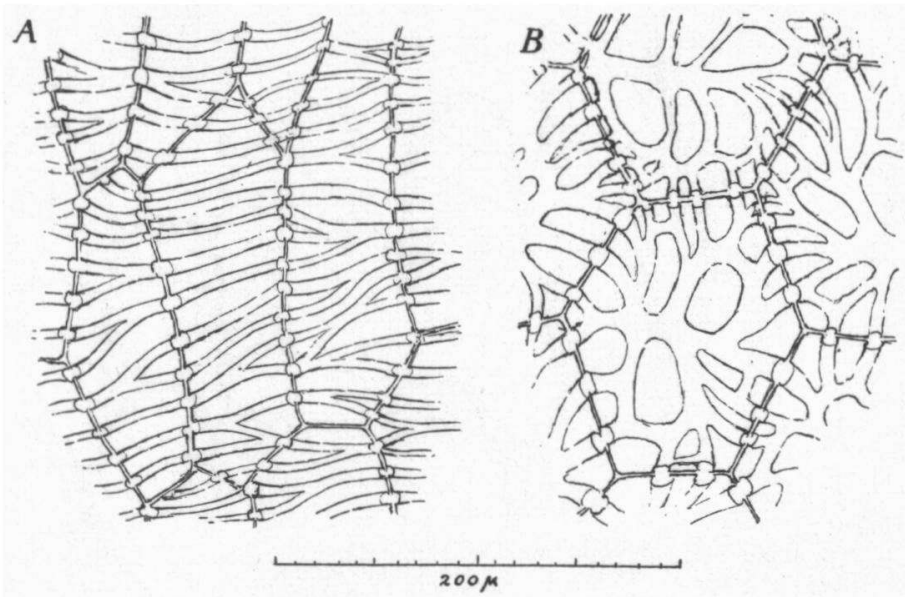

Fig. 7. Testa of A. Gleasonia duidana, and B. Gl. uaupensis.

over the lateral walls too. The nearest approach to this structure is found in Hillia Jacq., a genus which occupies a rather isolated position in the family, but which, i.a. on account of the presence of raphides, can certainly not be regarded as a near ally (see for this genus my work on "the African Species of Oldenlandia L sensu Hiern et K. Schumann" p. 14 and 15 and Tab. V fig. a); the cells of the Hillia testa, however, are of a different shape, and their lateral 
walls are much thicker. The structure of the testa cells shows that the genus Gleasonia, if it is to be included in the Rubiaceae, will have to be referred to a tribe or even to a subfamily of its own, and that it certainly can not be put in the Rondeletieae, as was done by Standley. In this tribe the basal wall of the testa cells is provided with very large round or oval pits, which means that it shows the structure which is characteristic for the subfamily to which this tribe belongs, viz. the Cinchonoideae sensu meo (see my paper on the subdivision of the family in "Rapports et Communications aux Sections 2, 4, 5 et 6, Huitième Congrès de Botanique: 113, 1954), and these large pits are in Gleasonia completely absent.

Now that we have finished our discussion of the indications the differences between Gleasonia and the genera Platycarpum and Henriquezia may give us with regard to the taxonomical position of these genera, it will be well to pay some attention to the points of resemblance in order to find out whether the latter do not invalidate the conclusions we have arrived at.

The main points of resemblance between the three genera are found in the large size of the pollen grains, a feature to which, as we have already pointed out, not much value can be attached, in the absence of endosperm in the ripe seed, in the structure of the embryo with its large cotyledons and its small axial part, in the shape and mode of dehiscence of the capsule, in the structure of the testa, in the pattern formed by the stomata and the surrounding epidermis cells on the lower side of the leaf, and in the presence of large resin cells in the twigs just outside the cambium.

Exalbuminous seeds were so far not known in any of the subfamilies of the Rubiaceae, although the amount of endosperm in the seeds of the Guettardoideae is but small, the embryo being of a larger size than is usual in the family. That the seeds of Gleasonia, Platycarpum and Henriquezia agree with each other in being exalbuminous, means that we experience with each of these genera in this respect the same difficulty when we try to find a place for them among the Rubiaceae, but as exalbuminous seeds occur in widely different circles of affinity, it certainly does not mean that they should of necessity be regarded as nearly allied.

That the cotyledons are very large in comparison with the axial part of the embryo is another feature on account of which it is difficult to find for these genera a place among the Rubiaceae, for even where in the embryo of plants belonging to this family fairly large cotyledons are noted, as in the genus Simira Aubl. (Sickingia Willd.), they prove to be hardly longer than the axial part. Howsoever this may be, this feature too can not be taken as proof of a near affinity between Gleasonia and the genera Platycarpum and Henriquezia, as embryos of this kind are certainly not confined to a single taxonomical group.

The resemblance in the shape of the capsule and in its mode of dehiscence need not detain us very long. The resemblance in shape is rather superficial, for the capsule of Gleasonia is completely inferior and by no means so strongly flattened as the semi-superior or entirely 
superior capsules of the two other genera, and the resemblance in the mode of dehiscence, which in all three is loculicidal, is taxonomically of no importance, as loculicidal capsules return in almost every order of the Angiosperms.

The resemblance in the structure of the testa, by which I was originally so strongly impressed that I overemphasized its taxonomical importance, appears now, after a more detailed investigation, to be of a rather superficial nature. It is true that in all three the genera the walls of the testa cells are strengthened by a network of thickenings, but this network is in Gleasonia met with in the convex outer wall and the lateral ones, whereas it is found in the two other genera on the basal wall; however, it must be admitted that, at least in Platycarpum, it is also present in the papillae, which are part of the outer wall. However, as testa cells with reticulate walls return in very different families, their taxonomical importance should not be overrated. It can not even be adduced as an argument for excluding these genera from the Rubiaceae, as in the genus Hillia Jacq. too the testa consists of reticulate cells.

The position of the stomata with regard to the surrounding epidermis cells on the underside of the leaf is in all three genera the same (Fig. 8). The pattern they form with these cells is the one that
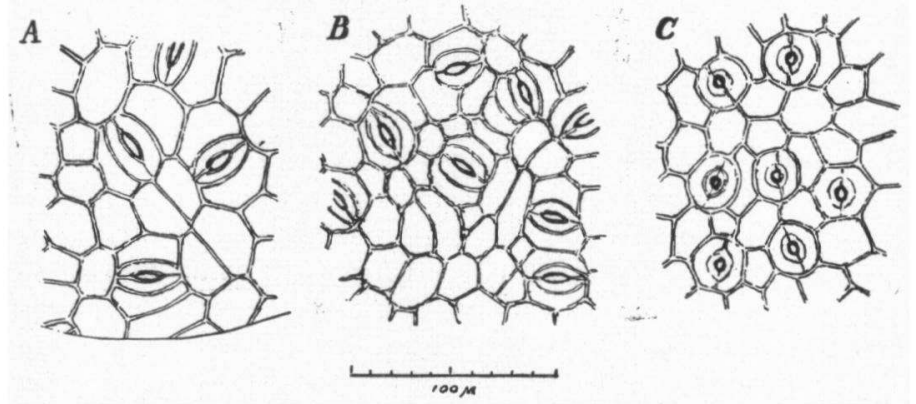

Fig. 8. Epidermis on the underside of the leaf of A. Gleasonia macrocalyx, B. Platycarpum negrense, and C. Henriquezia verticillata.

is typical for the Rubiaceae. This, however, does not prove that they belong to this family, for this pattern is not confined to it. It returns e.g. in some of the Bignoniaceae, i.e. in a family to which two of the three genera are supposed to be allied.

The presence of very large resin cells in the phloem is a similar character. Although such cells are apparently not of common occurrence in the Rubiaceae, they are not unknown in that family; they are found e.g. in the Gardenieae. They occur also in several other families. Precise knowledge with regard to these structures is, however, difficult to obtain, as herbarium specimens are not very suitable for their study.

Besides the points in which Gleasonia resembles Platycarpum as well as Henriquezia there is also a point in which it resembles only one of 
them, viz. Platycarpum. It is a very striking one, and it is found in the stipules which in both these genera are large and intrapetiolar. Especially the intrapetiolar position is a most remarkable feature, for intrapetiolar stipules, although at one time thought to be not uncommon in the Rubiaceae, are in reality, as I have pointed out at an earlier occasion (Bull. Jard. Bot. Buitenz. Sèr. 3: 13: 425. 1935) very rare. In fact, among the genera in which they had been recorded in the older literature Capirona Spruce ex Bth. proved to be the only one in which they are actually present. I must admit, however, that the description of Gleasonia was at that time overlooked by me, and add that with regard to the stipules of Platycarpum no reliable information was as yet available. I myself found them at that time in Didymoecium Brem. and recently also in Suteria DC. It is noteworthy that these genera belong to different tribes and partly even to different subfamilies, and that neither Gleasonia nor Platycarpum show in other respects a well-marked resemblance to any one of them. The taxonomical value of the intrapetiolar stipules must therefore be regarded as very small, and their presence in Gleasonia as well as in Platycarpum can therefore hardly be interpreted as indicating affinity between them. It seems that we are confronted here with a mere analogy, and this supposition finds support in the fact that the intrapetiolar stipules of Platycarpum appear to owe their origin to the splitting of an originally closed sheath, whereas those of Gleasonia seem to be free from the start. The stipules of Gleasonia, moreover, differ, as we have already seen, fundamentally from those of Platycarpum in the presence of colleters. In the absence of the latter there is complete agreement between the stipules of Platycarpum and those of Henriquezia, which at first sight look quite different, in the first place because they are rather narrow, and in the second place because there are two of them to each leaf. There is, however, agreement in so far that in Henriquezia too the stipules are at first united into a sheath which completely envelops the terminal bud.

\section{The position of the genus Gleasonia}

If we try to determine the position of the genus Gleasonia by the aid of the data given above, we come to the conclusion that the latter agrees in most of its characters with the notion we have, in the course of time, arrived at with regard to the family Rubiaceae; especially important in this respect are the decussate leaves, the stipules provided with colleters, the actinomorphous flowers with inferior ovary and sympetalous corolla, and the simple whorl of stamens alternating with the corolla lobes. The points in which it deviates from our notion of this family are the exalbuminous seeds, the structure of the embryo with its large cotyledons and comparatively small axis, and also, though this seems to be of somewhat less importance, in the large size of the pollen grains. The problem with which we are confronted, may therefore be formulated in this way: should we extend the limits of the family Rubiaceae so far that it becomes possible to include the 
aberrant genus Gleasonia, or is it preferable to create for this genus a new family?

The absence of endosperm is doubtless a character of great taxonomical importance. It is true that the amount may vary to some extent in a definite group, as it does e.g. in the Rubiaceae themselves, where we have one subfamily, the Guettardoideae, with but a comparatively thin layer of it, but the difference between albuminous and exalbuminous seeds is nevertheless, as a rule, well-marked, and it happens but rarely that one has any difficulty in deciding to what category a seed should be referred. Moreover, up to a certain rank we find in taxonomically well-defined groups, as a rule, but one of these kinds of seed. That the seeds of Gleasonia are undoubtedly exalbuminous, is therefore a strong argument for removing this genus from the Rubiaceae. If we will not go that length, we will have to widen the delimitation of the family, for as there is no place for our genus in any of the subfamilies, a new one will have to be created, and to make place for the latter, the limits of the family will have to be extended. If we decide that the delimitation of the family is better left unchanged, we will, of course, first of all have to find out whether there is a place for the genus in one of the other families of the Rubiales, for in view of the important points of resemblance with the Rubiaceae s.s. it need not be doubted that it belongs to this order. As there is here but one family with exalbuminous seeds, viz. the Valerianaceae, this question is easily settled: in the Valerianaceae there is certainly no place for our genus as the latter have exstipulate leaves and zygomorphous flowers with an incomplete androecium and gynoecium. The great taxonomical value of the points of resemblance between Gleasonia and the Rubiaceae creates a strong link between them, and brings them in opposition to the rest of the Rubiales, which means that they form a group that would have to be recognized as a suborder. For this reason we might formulate our problem also in this way: should we create for Gleasonia a new family, and for the latter and the Rubiaceae s.s. a new suborder, or should we leave the genus in the Rubiaceae, of which in this case the delimitation should be widened?

In order to find a solution for the problem formulated in the preceding paragraph, we will have to find out whether the differences between Gleasonia and the subfamilies that so far have been recognized within the Rubiaceae, are of greater taxonomical importance than those existing between any two of them, for if the differences between some of the latter would prove to be of greater importance, there would certainly be no reason to create a new family for Gleasonia. If, on the other hand, the differences between these subfamilies would prove to be of less importance than those between Gleasonia and the whole group, then the creation of a mere subfamily would hardly be sufficient.

The main points in which Gleasonia differs from the whole set of subfamilies are the exalbuminous seed and the structure of the embryo with its large cotyledons and short axis. It differs moreover from the 
Cinchonoideae sensu meo in the absence of the large oval or orbicular pits on the basal walls of the testa cells, from the Urophylloideae by the much thinner, not finely perforated walls of the testa cells, from the Ophiorrhizoideae in the absence of the peculiar wartlets on the walls of the testa cells, from the Guettardoideae in the entirely different fruit and also in the absence of crystals of calcium oxalate in the walls of the hairs by which the various parts are covered, from the Ixoroideae in the totally different structure of the upper part of the style, which does not function as "receptaculum pollinis", and from the Rubioideae by the absence of raphides.

That Gleasonia is fundamentally different from each of the subfamilies that hitherto have been recognized in the Rubiaceae, can therefore not be doubted, and when we were to obey our first impulse, we would hardly hesitate to decide that it is more fundamentally different from the whole set than any two of them are from each other. We should realize, however, that all these subfamilies consist of more than one genus, most of them even of a very large number, and that the differences between them would doubtless be more numerous and therefore more impressive if each of them was represented, like the group to which Gleasonia belongs, by a single genus only. For this reason it seems hardly possible to decide the question in an entirely objective way, and as the introduction of a new subfamily answers our present needs, and will probably meet with less resistance than the introduction of a new family would do, it seems prudent for the time being to go no further.

The exposition given above is summarized in the following description of the new subfamily.

Gleasonioideae nova subfamilia Rubiacearum a subfamiliis aliis seminibus exalbuminosis et embryone cotyledonibus parte axili majoribus instructo faciliter distinguenda.

Arbores. Folia opposita, petiolata. Stipulae magnae, intrapetiolares, simplices. Inflorescentiae terminales, corymbi- vel paniculiformes. Flores pentameri, actinomorphi, magni. Ovarium biloculare, utroque loculo ovulis pluribus instructo; ovula in serie verticali duplici dimidio inferiore septi inserta. Calyx regularis, in lobos longos partitus; lobi albi, post anthesin decidui. Corolla satis magna, extus sericea, tubo infundibuliformi sensim in faucem ampliato, lobis aestivatione induplicativa. Stamina fauce inserta; antherae exsertae. Granula pollinis tricolpata, magna, in tetrades unita. Stylus in stigmata dua exeuns, breviter exsertus. Fructus (Fig. 9) capsula complanata, loculicide dehiscens, utroque loculo seminibus pluribus instructa. Semina angulosa, exalbuminosa; embryo cotyledonibus crassis parte axili majoribus instructus; testa e cellulis convexis composita, pariete externa reticulatione laxa invigorata.

Subfamilia adhuc e genere unico constans, Americae Tropicalis incola.

As this subfamily comprises but a single genus, it also contains but a single tribe. It seems superfluous to describe the latter; if it should receive a name, this, of course, would have to be Gleasonieae.

The genus Gleasonia Standl. comprises at present three species, $G l$. 
duidana Standl., Gl. uaupensis Ducke and Gl. macrocalyx Ducke, all three confined to Tropical South America, the first to Amazonian Venezuela, the two others to Amazonian Brazil. Gl. duidana and Gl. uaupensis are now comparatively well-known; they are doubtless nearly related species, differing but slightly in the length of the petioles, the size of the leafblade and of the stipules, the length and width of the calyx

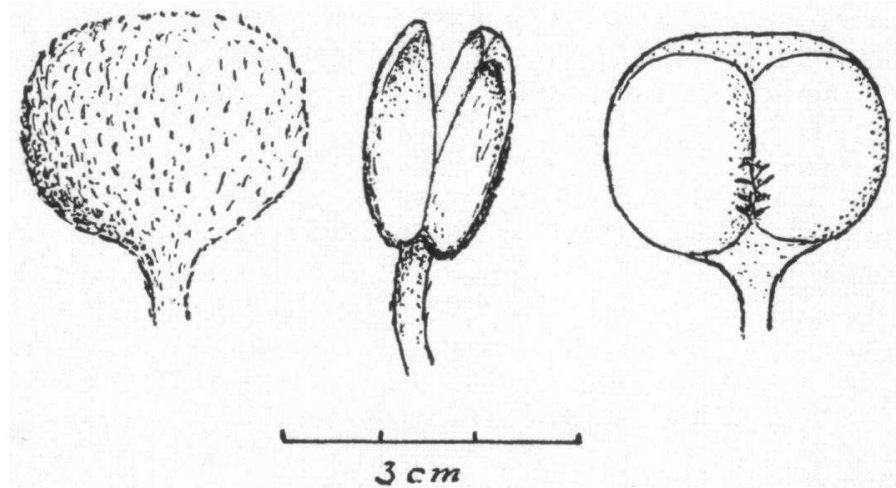

Fig. 9. Capsule of Gleasonia uaupensis.

lobes, the size of the corolla, the size of the pollen grains (cf. p. 356) and the structure of the testa; Gl. uaupensis, moreover, is, as Ducke already reported, a myrmecophilous species, the concave stipules sheltering small red ants. The third species, $G l$. macrocalyx, differs conspicuously from the two others in the absence of the hirsute indumentum, in the much larger size of the fruit, and in the presence of wartlets on the testa; this species is unfortunately still very imperfectly known. As in all specimens that so far have been collected, the corolla had already been shed, and as none of them were provided with fully ripe fruits, the very important characters of the pollen and of the mature testa could not yet be studied. So long as these characters are unknown, it is hardly possible to decide whether this species really belongs to the genus Gleasonia. However, as its seeds are exalbuminous and as its embryo is provided with large cotyledons, it is not to be expected that it will have to be referred to another subfamily.

The position of the genera Platycarpum and Henriquezia

The absence of endosperm and the large size the cotyledons reach in comparison with the axial part of the embryo are two important characters in which, as we have seen, the genera Platycarpum and Henriquezia resemble Gleasonia and in which they all three differ from the general plan of the Rubiaceae, but Platycarpum and Henriquezia differ from the latter also in some important points in which Gleasonia is consistent with it. These points are 1) the absence of colleters on the inside of the stipules, 2) the presence of a band of hairs on the ventral side of the corolla throat and the distinctly zygomorphous androecium, and 3) the semi-superior or even almost completely 
superior capsule. Each of these deviations from the general plan would already in itself form an important argument against the inclusion of these genera, but put together their weight becomes so overwhelming that it will crush every attempt in this direction. The presence of a strip of hairs on the ventral side of the corolla throat and the distinctly zygomorphous androecium, moreover, point towards an entirely different circle of affinity, viz. that of the Tubiflorae, where we find in the Bignoniaceae, Pedaliaceae, Thunbergiaceae, Mendonciaceae and Acanthaceae a group of families with which the genera Platycarpum and Henriquezia show a quite remarkable resemblance in habit; in fact, this resemblance is much more pronounced than that with the Rubiaceae.

When Humbold and Bonpland described the genus Platycarpum (Plantae aequinoctiales 2: 81, tab. 104. 1809) they were apparently so impressed by the resemblance meant in the preceding paragraph that they placed their new genus without any hesitation in the Bignoniaceae. On account of the inferior ovary, the position of the ovules and the presence of stipules, this is, of course, an unacceptable decision, but these characters were either misunderstood or overlooked by them. It can not be doubted that they regarded the ovary as superior, for they described the calyx as inferior, probably because they found the scar of the latter near the base of the capsule, and did not realize that by far the greater part of the latter owes its origin to the very strong development of the portion inside the calyx; and that they overlooked the presence of stipules is also easily comprehensible, as the latter are early deciduous and, as a rule, present only round the terminal bud; it is quite possible that all the branches they had collected ended in inflorescences, and in that case probably not a single stipule would have been present. That the seeds are described as provided with a membranaceous margin, is not correct either; it applies only to young seeds where the space inside the testa is not yet completely filled up by the embryo. A similar mistake was made by Bentham when he described the seeds of Henriquezia as marginate, though to be quite fair to him I must admit that he cautiously added the words "ut videtur". Here too in the fully mature seeds the whole space inside the testa is occupied by the embryo, and there is no trace of a wing. J. D. Hooker (in Bentham et Hooker, Gen. Pl. 2: 12. 1873), to be sure, was entirely mistaken when he described the seeds of the Henriquezieae, the tribe created by him for the reception of the genera Henriquezia and Platycarpum, as "latissime alata".

The authors who like Fenzl (Denkschr. d. k. bayer. bot. Gesellsch. 3: 239 et 265. 1841), De Candolle (Prodr. 9: 233. 1845) and Bureau (Monographie des Bignoniacées: 80-81 et 103. Paris 1864) in the next half century occupied themselves with Platycarpum, accepted Humbold and Bonpland's classification, but they too overlooked the presence of stipules and the inferior position of the ovary.

When BENTHAM described his new genus Henriquezia (Kew Journ. of Bot. 6: 337. 1854), he duly mentioned its near affinity with Platycarpum, and referred it, just as his predecessors had done with the 
a tter, to the Bignoniaceae, and like them he failed to specify his reasons. It is well to remember this when we look at the arguments he adduced in support of his view that the two genera are nearly allied. They read as follows: "The five equal and perfect stamens, and the short broad fruit with very few seeds, are the same, as well as the general habit and simple leaves." If the two genera really belonged to the Bignoniaceae, these characters would suffice to contrast them with the rest of the family, and this in its turn would bring them in closer contact with each other. However, as soon as we drop the notion that they belong to this family, these characters loose a great deal of their value, for then they appear to be features of a rather general nature, which return in very different circles of affinity. This applies especially to the first-named characters, the five perfect stamens and the simple leaves, but even the presence of short and broad fruits with a small number of seeds can not be regarded as a very special character, and it looses, moreover, much of its value when we realize that the capsules of the two genera are in other respects quite different, for that of Platycarpum proves to be almost completely superior and in dehiscence the right and left half of each valve fold backwards until they meet, whereas the capsule of Henriquezia is only semisuperior and its valves in separating do not appreciably change their form. This difference in the mode of dehiscence was unknown to the earlier authors who had no ripe fruits at their disposition. When Bentham said that the stamens in the two genera are all equal, he was mistaken, for they are in reality quite distinctly unequal. It is rather unfortunate that this inequality escaped his attention, and also that the overlooked the bent at the base of the filaments, for the presence of a zygomorphous androecium of this kind is one of the most important points of resemblance between these genera and the Bignoniaceae and their nearest allies.

The more important points of resemblance between Henriquezia and Platycarpum were omitted by Bentham, partly, no doubt, because he regarded them as general characters of the Bignoniaceae, the family to which the genera were referred by him, and partly, because they were overlooked. To the first group apparently belong the flat, exalbuminous seeds, which erroneously were regarded as winged, and the structure of the embryo with its large and flat cotyledons; to the second the remarkable "glands" at the base of the petiole, the presence of stipules, the complete but distinctly zygomorphous androecium, and the collateral ovules. That he overlooked the importance of the petiolar "gland" is rather surprising, because the presence of this organ is in his description of Henriquezia verticillata duly recorded; that he would have overlooked its presence in Platycarpum, seems therefore hardly possible. I suppose that the omission was merely accidental.

The way in which he summarizes the points of difference between the two genera is not very satisfactory either. According to him Henriquezia differs from Platycarpum in "the semi-adherent calyx with a persistent base and only four lobes, and the shape of the corolla, 
so much more Bignoniaceous than that of Platycarpum". The calyx, however, is not semi-adherent but totally adherent; only when the fruit begins to grow out, the calyx gradually shifts from the top to a position midway between the latter and the base; and its base can hardly be called persistent: in this respect I see no difference at all between the two genera. That some of the Platycarpum species too possess but four calyx lobes, he could not know, as these species had not yet been collected. The corolla of Henriquezia is much larger than that of Platycarpum, but in shape it is hardly different from the latter. The really important points of difference were as yet overlooked; they are found in the nature of the stipules, in the number of ovules and in the characters of the fruit. The stipules of Henriquezia are narrow and there are two of them to each petiole, those of Platycarpum are wide and intrapetiolar; in Henriquezia they are, moreover, inserted on the petioles and shed with the latter, whereas in Platycarpum they are inserted on the stem, and leave a scar that surrounds the stem and passes above the base of the petioles. The ovary cells of Henriquezia contain four ovules, those of Platycarpum two. The capsule of Henriquezia is semi-superior, oblate-lenticular, and provided with valves that after dehiscence retain their shape, whereas that of Platycarpum is almost completely superior, discoid, and provided with valves of which the right and left half after dehiscence fold back until they meet.

J. D. Hooker (in Bentham et Hooker, Gen. Pl. 2: 12. 1873) accepted Bentham's view with regard to the near affinity between the two genera, and brought this out by uniting them into a tribe, for which he introduced the name Henriquezieae. He differed, however, from Bentham and the latter's predecessors with regard to the place that would have to be assigned to them, and instead of to the Bignoniaceae he referred his new tribe to the Rubiaceae. It is not quite clear why he did this, for the points in which they differ from the general plan of this family and in which they agree with the Bignoniaceae, the zygomorphous corolla and the exalbuminous seeds, are duly mentioned in his description. The zygomorphism of the flower is even somewhat overemphasized, for the corolla is described as bilabiate, whereas the lobes are in reality but slightly unequal and certainly not united into an upper and a lower lip. The very distinct zygomorphism of the androecium, on the other hand, is not specially mentioned. We must assume therefore that he did not attach much weight to these characters, and thought the position of the ovary, which he described as semi-superior, and the presence of stipules, which he was the first to mention, of greater importance. That this would be so, however, seems very dubious, for semi-superior and even entirely inferior ovaries, although not present in the Bignoniaceae themselves, are not unknown in the order to which the latter belong. As Bentham already remarked, they occur in one of the subfamilies of the Gesneriaceae. Stipules, it is true, do not occur in this order, but as their distribution in the various orders is rather erratic, their presence can not be regarded as a suffi- 
cient ground to exclude these genera from an order in which stipules were so far regarded as absent.

The diagnostic characters which Hooker mentioned in his key to the genera, have been taken from the calyx. Henriquezia is characterized by "Calycis limbus circumscisse deciduus" and Platycarpum by "Calycis limbus 5-lobus". The expression "circumscisse deciduus" is not quite clear. I can not believe that it refers to the way in which the upper part of the calyx is separated from the hardly noticeable base, for in this respect there is not much difference with Platycarpum; I prefer to suppose that it refers to the scar left by the calyx on the surface of the fruit; this scar is found midway between the top and the base, i.e. in the place where a "capsula circumscissa" would open: in the position of this scar there is indeed a very marked difference between the two genera, for in Platycarpum it is found quite near to the top of the pedicel. That in Platycarpum too species with four calyx lobes are found, was, as mentioned above, in Hooker's time unknown.

SchumanN (in Fl. Bras. VI, 6: 133. 1889 and in ENGler and PrantL, Nat. Pflanzenfam. IV, 14: 39. 1891) adopted Hooker's classification, but he too failed to make this decision clear. Nevertheless he seems to have felt the difficulty caused by the zygomorphism of the flower, for in this light I wish to see his remark that Hooker's Henriquezieae form by means of some other genera with zygomorphous flowers, like Capirona, Coutarea and Ferdinandusa, a link between the Cinchoneae and the Bignoniaceae. This is, if taken literally, a rather strange assertion, for it presupposes that the kind of zygomorphism found in the flowers of the Bignoniaceae and in those of Platycarpum and Henriquezia is homologous with the zygomorphism shown by the flowers of Capirona, Coutarea and Ferdinandusa. However, that a character found in one order in part of the genera of a single family can be regarded as homologous with a character observed in a family belonging to a different order, is certainly a rare exception, for it demands that the character is part of the general plan of the next higher unit, viz. the one that comprises both these orders; in our case this is hardly to be expected. Moreover, the resemblance between the zygomorphism shown by the flowers of the Bignoniaceae and of Platycarpum and Henriquezia and that seen in the flowers of Capirona, Coutarea and Ferdinandusa is very superficial indeed, and can therefore not be regarded as indicating homology. The most characteristic features of the zygomorphism shown by the flowers of the Bignoniaceae and of Platycarpum and Henriquezia are found in the insertion of the stamens at different height and in the bent at the base of the filaments, and these features are completely absent in the flowers of Capirona, Coutarea and Ferdinandusa, where the zygomorphism is confined to a slight curvature of the corolla and a corresponding difference in the length of the filaments. The first kind of zygomorphism is characteristic for a large part of the Tubiflorae, whereas the second is but a slight modification of the actinomorphism that is typical for the Rubiales. The zygomorphism of Platycarpum and Henriquezia is therefore no link between that of the Bignoniaceae and that of the genera Capirona, Coutarea and 
Ferdinandusa and via the latter with the actinomorphism of the other Rubiaceae, but it is fully identical with that of the Bignoniaceae and quite different from that of Capirona, Coutarea and Ferdinandusa.

The characters used by Schumann in his key to the genera, viz. for Platycarpum "Flowers nearly hypocrateriform, vertical. Calyx lobes singly deciduous. Leaves decussate", and for Henriquezia "Flowers bilabiate, horizontal. Calyx circumscissile. Leaves verticillate", are inadequate. Neither in the shape of the corolla nor in the position of the flower any well-marked difference is observable; the calyx is shed in both genera in the same way; and species with verticillate leaves are, as we now know, found in Platycarpum too.

In his monograph of the genus Platycarpum STEYermark (Am. Journ. of Bot. 39: 418-429. 1952) also followed Hooker in referring the Henriquezieae to the Rubiaceae, but he too gave no arguments. In his key to the genera he introduced a new diagnostic character, viz. the number of ovules in the ovary cells, 2 in Platycarpum, 4 in Henriquezia. This is a reliable difference, though less easily discernible than the differences in the stipules ( $P l .:$ as many as the leaves and wide; $H$. : twice as many as the leaves and narrow) and in the capsule ( $P l$ : : discoid and almost entirely superior, the right and left half of each valve folding back until they meet; and $H$. : oblate-lenticular and semi-superior, the right and left half of the valves not folding back), which are not mentioned.

From this survey of the literature and from the remarks $I$ have inserted here and there we may conclude that the genera Platycarpum and Henriquezia are near enough to each other and at the same time sufficiently distinct from other genera to be united into a taxonomical group to which at least the rank of a tribe will have to be assigned. Further it seems clear that this group can not be inserted in the Bignoniaceae, as they differ from the latter in such important points as the inferior ovary, the collateral ovules and the presence of stipules. The peculiar kind of zygomorphism shown by the flower, however, suggests a nearer affinity with this family than with the family Rubiaceae, to which they were referred by Hooker. From the general plan of the latter they differ not only in the presence of the strip of hairs on the ventral side of the corolla throat and in the zygomorphism of the androecium but also in the absence of colleters on the inside of the stipules, in the exalbuminous seeds and in the structure of the embryo with its large cotyledons and small axial part. The two latter characters are found also in the genus Gleasonia, which, as we have pointed out, is to be referred either to the Rubiaceae themselves or else to a very closely related family, and their presence in the Henriquezieae can therefore not be regarded as a factor of decisive importance, but the combination of the first-named characters, the peculiar kind of zygomorphism which finds its expression in the presence of a strip of hairs on the ventral side of the corolla throat and in the zygomorphous androecium, and the absence of colleters, is doubtless of so outstanding significance that it fully justifies the exclusion of these genera from the Rubiaceae. The peculiar type of zygomorphism ex- 
hibited by their flowers, moreover, points in a different direction, viz. in that of the Tubiflorae.

The presence of an inferior ovary makes it impossible to return the group to the Bignoniaceae, but it does not prevent us from referring it to the order of which the latter form a part, as in one of the other families, the Gesneriaceae, such ovaries are by no means uncommon. The collateral ovules form no obstacle either, as this kind of arrangement of the ovules is certainly not unknown in the Tubiflorae; it occurs here in two families that are to be regarded as near allies of the Bignoniaceae, viz. the Thunbergiaceae and the Mendonciaceae, and also in the Labiatae. The presence of stipules might seem, at first sight, to offer a greater difficulty, as stipules are indeed entirely unknown in the Tubiflorae, but we should realize that the groups in which they occur, are of very different taxonomical rank, and that they are rather irregularly spread over the various orders. That the Tubiflorae were so far regarded as an order in which stipules are absent, is therefore no sufficient ground for excluding a group in which they are present.

That the genera Platycarpum and Henriquezia can not belong to the Rubiaceae, would not necessarily mean that there is no place for them in the Rubiales, i.e. in the order to which the Rubiaceae belong. This is doubtless a possibility that deserves careful consideration. It is certainly easy to see that they can not belong to one of the families that so far have been recognized in this order, for there is only one among them that agrees with our genera in the presence of exalbuminous seeds, and this family, the Valerianaceae, differs from them in the exstipulate leaves and in the incomplete androecium and gynoecium. The possibility that they might form a distinct family is, on the other hand, not so easily discarded, as the order is but poorly defined, so that it is difficult to say what might or might not belong to it. At any rate, as the Rubiaceae are the only family with some of whose representatives our two genera show a certain resemblance, and as this resemblance may, on good grounds, be regarded as a mere analogy, the insertion of such a new family in this order can not be regarded as a plausible solution of our problem. The peculiar type of zygomorphism shown by the flowers of our two genera is, at any rate, a feature that looks entirely out of place in this order.

The foregoing considerations lead to the conclusion that the genera Platycarpum and Henriquezia form a well-defined group, for which there seems to be no place in the Rubiales, but which fits very well into the order Tubiflorae, although it can apparently not be referred to one of the families that so far have been recognized. On account of the large exalbuminous seeds it would have to be referred to a position in the neighbourhood of the Bignoniaceae, Pedaliaceae, Martyniaceae, Thunbergiaceae, Mendonciaceae and Acanthaceae; in the structure of the pollen grains there is moreover some resemblance with the Pedaliaceae and the Bignoniaceae; in the collateral ovules with the Thunbergiaceae and the Mendonciaceae; in habit and especially in the form of the fruit, which is flattened perpendicular to the dissepiment, they remind one, as Fenzl already remarked, of the Tecomeae (Bigno- 
niaceae); and in the large and flat, wingless seeds of some of the Pedaliaceae.

The genera Platycarpum and Henriquezia therefore are to be united into a group that will have to receive the rank of a family, and for which a place will have to be found in the order Tubiflorae. As the two genera were already united by Hooker into a tribe Henriquezieae, the name Henriqueziaceae seems to be indicated for this family. It is true that Hooker might perhaps better have derived the name for his tribe from Platycarpum, as that name has much older rights than Henriquezia. In fact, some years later BaILLON too (Hist. d. Pl. 7: 345 et 487. 1880) united the genera into a group, but as he judged the differences between them of minor importance, he did not regard this group as a tribe but as a genus, and for this genus he had, of course, to use the name Platycarpum. This means that if Baillon's view were to be accepted, the name of the tribe as well as that of the family would have to be derived from Platycarpum. However, as there is no reason to assume that later botanists will return to Baillon's standpoint, it seems safe to base the name of the family on that of Hooker's tribe. The family may be described as follows:

Henriqueziaceae familia nova Tubiforarum praesentia stipularum et "glandulae petiolaris" a familiis aliis diversa, seminibus exalbuminosis ad Bignoniaceas, Pedaliaceas, Martyniaceas, Thunbergiaceas, Mendonciaceas et Acanthaceas accedens sed ab eis absque stipulis et glandula petiolari ovario infero distincta, structura pollinis cum Bignoniaceis et Pedaliaceis, ovulis collateralibus cum Thunbergiaceis et Mendonciaceis congruens, habitu et forma capsularum inter Bignoniaceas Tecomeis nonnullis, seminibus complanatis et exalatis Pedaliaceis aliquibus comparanda.

Arbores parvae vel mediocres. Folia decussata vel verticillata, petiolata et stipulata, simplicia et integerrima; petiolus ad basin dorso "glandula" laevi, sicc. nigrescente instructus. Stipulae sine colletris. Flores in inflorescentias terminales, paniculiformes dispositi. Ovarium inferum, biloculare, utroque loculo ovulis $2-4$ collateralibus instructum. Calyx fere ad basin 4- vel 5-partitus, post anthesin deciduus. Corolla semper 5-mera, paulum zygomorpha, extus pubescens, tubo in faucem campanulatam ampliato, intus ad insertionem staminum barbato et virga pilorum e basi lobi mediani descendente percurso, lobis subaequalibus obtusis, aestivatione adscendente imbricatis. Stamina 5 ad altitudines inaequales inserta, inclusa; filamenta basi curvata, inaequilonga; antherae dorsifixae, basi sagittatae, loculis parallelis. Granula pollinis satis magna, colpis 3-6 instructa. Discus annularis. Stylus glaber, ad altitudinem antherarum in stigmata 2 exeuns. Capsula semi-supera et oblato-lenticularis vel fere tota supera et discoidea, dissepimento angusto instructa, loculicide dehiscens, utroque loculo semina 2 vel 4 continens. Semina valde complanata sed exalata, exalbuminosa, cellulis testae in papillas exeuntibus; embryo cotyledonibus planis et magnis et axi brevi instructus.

Generibus 2 in parte Americae Tropicalis Amazonica dicta distributa. 
The two genera are easily distinguishable by means of the differences given in the following key.

\section{Key to the Genera of the Henriqueziaceae}

1. Stipules as many as leaves, inserted on the stem, intrapetiolar and ovate. Flowers comparatively small, i.e. corolla less than 2 cm long. Ovary cells with 2 ovules. Pollen grains 3- or 4-colpate (Fig. 4). Capsule discoid, almost entirely superior, i.e. the scars of calyx and corolla near the top of the pedicel; valves consisting of a right and left half which after dehiscence fold back until they meet (Fig. 10). Testa cells with straight walls (Fig. 5) . .
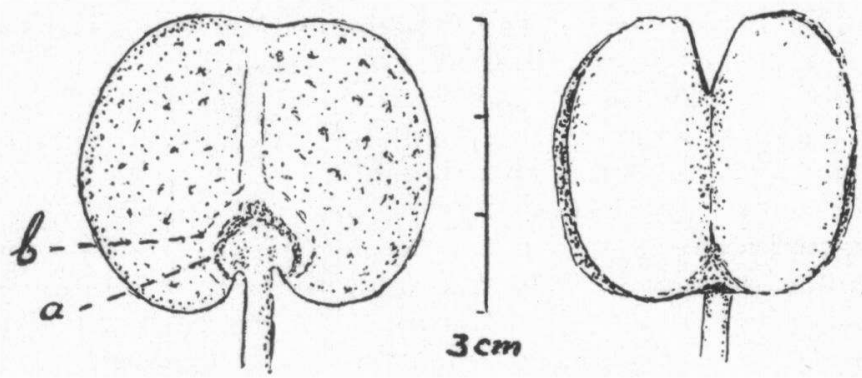

Fig. 10. Capsule of Platycarpum orinocense before and after dehiscence; a. scar of calyx; b. scar of corolla.

1: Stipules twice as many as leaves, inserted on the petioles, linear. Flowers large, i.e. corolla more than $3 \mathrm{~cm}$ long. Ovary cells with 3 or 4 ovules. Pollen grains 5- or 6- colpate (Fig. 4). Capsule oblate-lenticular, semi-superior, i.e. the scar of the calyx midway between the top and the base, and that of the corolla midway between the top and the scar left by the calyx; valves not consisting of mobile halves (Fig. 11). Testa cells with undulating walls (Fig. 6) . . . . . . . . . . . . . . Henriquezia.

There are still a number of species of which flower and fruit are either unknown or but imperfectly known. However, in view of the great uniformity shown by those that could be studied in sufficient detail, there seems to be good reason to expect that the other ones will not deviate too much. Still, with regard to the characters of the pollen grains and especially of the testa cells some reserve should be made, as the pollen grains could be studied only in a small number of species, and as in the genus Henriquezia seeds were available only from the type species. The most reliable characters nevertheless are those of the stipules, and the latter are also the most useful ones, as they may serve even when neither flowers nor fruits are available; even when they themselves have been shed, their scar can enlighten us with regard to the position they occupied, and this is enough.

In the structure of the pollen grains the difference seems to be 
greater than the key indicates, for, as the figures show, they differ not only in the number of colpae but also in size, outline and relief.

It does not seem necessary to give new latin descriptions of the two genera, for although the existing ones are not entirely satisfactory, they can easily be extended and corrected by means of the data contained in the key and in the description of the family.

The genus Platycarpum was not so long ago revised by STEYermark 1.c., who brought the number of species to five. A sixth species will be described below, and of a seventh species material was collected
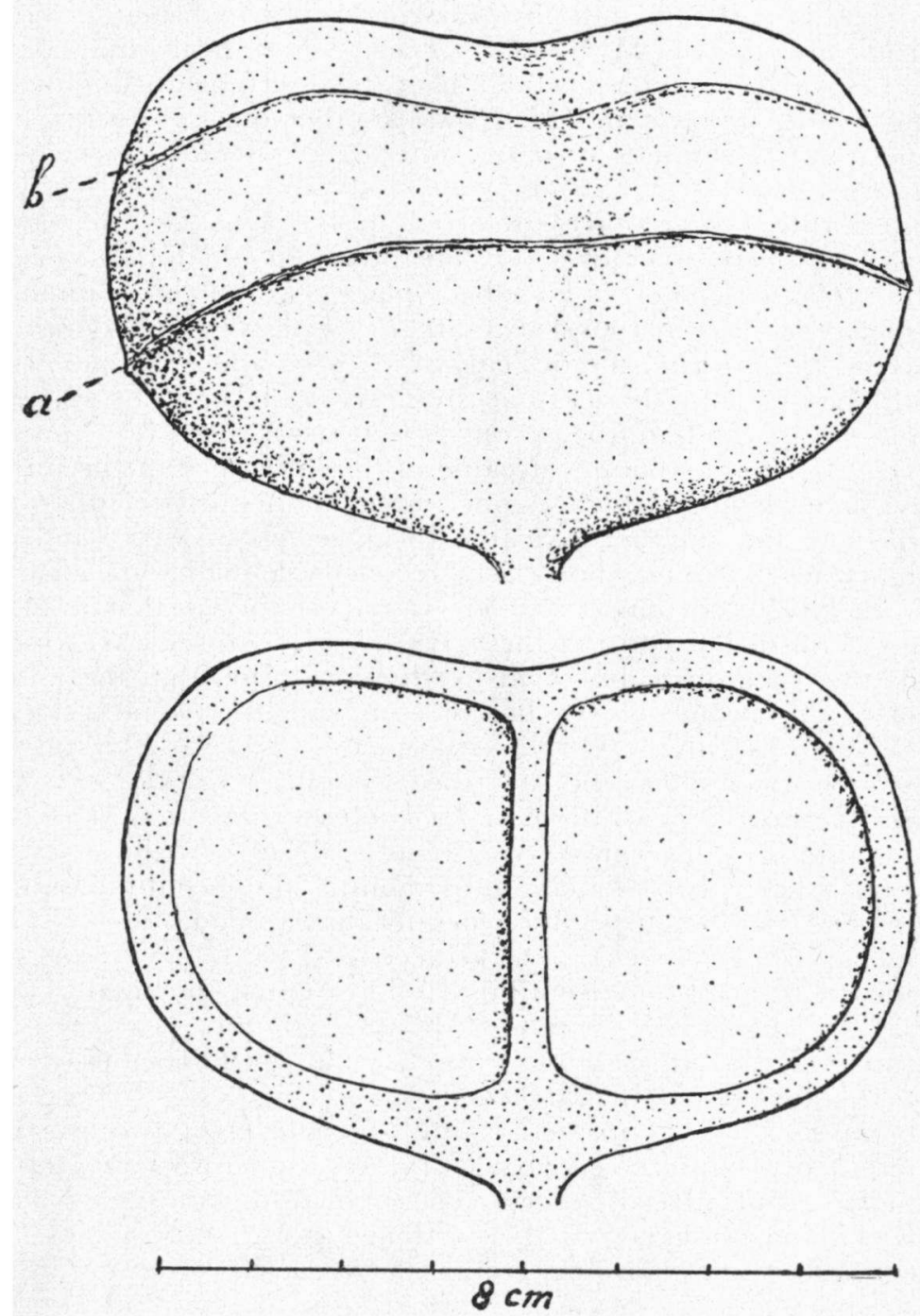

Fig. 11. Capsule of Henriquezia verticillata; a. scar of calyx; b. scar of corolla. 
in British Guiana (Paharaina Mts, Mt Ayanganna, Maguire e.a. 40666 $\mathrm{NY}$ ); it resembles $P l$. Duckei Steyermark, but has much larger capsules; as no flowers were available, it seems better to leave it unnamed.

Steyermark based his key to the species mainly on the presence or absence of an indumentum, and on the latter's distribution and quality. It is not to be expected that this will lead to a fully natural classification, but in view of the near affinity between the species, a better arrangement will probably be difficult to obtain, and it can not be denied that the species that so far have been described, are in this way easily identifiable. Moreover, it was the only way that was open to him, as he had to include his $P l$. decipiens, of which neither flowers nor fruits are known. My own Pl. Froesii could easily find a place in his key; to this end we would have to insert before his division leading to $P l$. orinocense and $P l$. Duckei another one contrasting these two species on account of their opposite leaves with Pl. Froesii, whose leaves are ternate.

One might perhaps have preferred to base the key in the first instance on the number of calyx lobes, were it not for Pl. decipiens, which in this case could not have been placed, as its calyx is unknown. The species with 5-merous calyx are $P l$. orinocense, $P l$. negrense and Pl. Froessii, those with 4-merous calyx Pl. Duckei and Pl. rhododactylum; in both these groups there is one species with ternate leaves, in the first $P l$. Froesii, and in the second $P l$. rhododactylum. It is possible, however, that the taxonomical value of the difference in the number of calyx lobes is not so high as one might be inclined to suppose; in $P l$. orinocense the number of calyx lobes seems to vary, and such variability is, of course, not easily reconcilable with our idea of a taxonomically important character. It is perhaps worth noting that a comparison of the position the calyx lobes occupy in the 4-merous and in the 5-merous calyx, leads to the conclusion that the anterior lobe of the 4-merous calyx is homologous with the two anterior ones of the 5-merous calyx.

The new species may be described as follows:

Platycarpum Froesii Brem. n. spec. foliis ternatis cum Pl. rhododactylo Woodson et Steyermark congruens, sed calyce 5-mero et foliis minoribus, supra scabridis et subtus molliter pubescentibus, numero minore nervorum percursis ab eo faciliter distinguenda, calyce 5-mero et foliis parvis ad Pl. negrense Ducke accedens, sed foliis ternatis supra scabridis et subtus pubescentibus, inflorescentia tomentella $a b$ eo diversa, a $\mathrm{Pl}$. orinocensi Humb. et Bonpl., ad quem calyce 5-mero et indumento foliorum accedit, foliis et ternatis et minoribus, numero minore nervorum percursis recedens.

Arbor parva, circ. $4 \mathrm{~m}$ alta. Ramuli novelli ferrugineo-tomentosi, veteriores cortice nigrescente, sicc. plicatulo vestiti. Folia ternata; petiolus glandula basali excepta ferrugineo-tomentosus, $2-4 \mathrm{~mm}$ longus; lamina oblonga, $6.5-8.5 \mathrm{~cm}$ longa et $2.2-3.8 \mathrm{~cm}$ lata, apice obtusa, basi acuta, margine recurvata, coriacea, paulum discolor, sicc. brunnescens, supra costa dense strigosa excepta primum pilis satis longis sparsa, mox pilis rejectis scabrida, subtus costa tomentella, 
nervis venulisque pubescens, costa subtus prominente, nervis utroque latere costae 11 vel 12 subtus prominulis, venulis dense reticulatis utrimque distinguendis. Stipularum calyptra longe ferrugineo-villosa. Inflorescentia pedunculo ferrugineo-tomentello $2-3 \mathrm{~cm}$ longo elata, rachide $7-8 \mathrm{~cm}$ longa, ramulis ternatis, verticello primo et interdum secundo foliis ordinariis vel magnitudine aliquantulo redactis suffultis, ramulis aliis pedicellisque ebracteatis; rachis, ramuli pedicellique ut pedunculus ferrugineo-tomentelli. Calyx 5-merus. Corella rubra et fragrans dicta, matura nondum visa. Capsula etiam ignota.

Habitat Amazoniam Brasiliensem.

Brazil: Amazonas; Rio Negro, Preto, Matupiry, Froés 22812, Nov. 1947, type (U); "in open country".

Froés 22812 was distributed by the "Instituto Agronomico do Norte" under the name "Platycarpum negrense Ducke", but it is easily distinguishable from that spedies by the ternate instead of opposite, on the upper side scabrid and on the lower softly pubescent leaves and by the somewhat greater length of the hairs by which the various parts of the inflorescence are covered. By its ternate leaves it resembles $P l$. rhododactylum Woodson et Steyermark, but the latter has a 4-merous calyx and its leaves are on the upper side entirely glabrous and on the lower nearly so, for the very small papillae by which they are covered on this side are seen only by the aid of a lens.

The genus Henriquezia has received but little attention in recent years, and the number of its species has increased but slowly. It is now six, the latest addition being $H$. macrophylla Ducke. Below a seventh species will be described, viz. $H$. longisepala.

In this genus too the species are all closely related, and it is therefore difficult to arrange them in natural groups. They are, however, easily distinguishable, and this is mainly due to the following sets of differences, 1) stipules deciduous, i.e. shed shortly after the whorl of leaves to which they belong, begins to expand, or stipules persistent, i.e. shed at the same time as the leaves to which they belong; 2) leaves 5-, 4- or 3-nate; and 3) nerves on the underside of the leaf prominent or not. Less important differences are found in the length of the calyx lobes, in the shape of the leaf and the number of lateral nerves, in the nature of the indumentum, and in the colour the leaves assume in drying. Deciduous stipules are found in $H$. verticillata Spruce ex Bth. with 4- or 5-nate leaves and prominent nerves, in $H$. obovata Spruce ex Bth. with 4-nate leaves of a somewhat different shape but also with prominent nerves, and in $H$. oblonga Spruce ex Bth. with 3-nate leaves and non-prominent nerves; persistent stipules are met with in $H$. macrophylla Ducke with 4-nate leaves and prominent nerves, in $H$. Jenmanii $K$. Sch. with 3-nate leaves and prominent nerves, the only species with acute, on the underside greyish-tomentellous leaves, in $H$. nitida Spruce ex Bth. with 3-nate leaves and non-prominent nerves, and in $H$. longisepala Brem. also with 3-nate leaves and nonprominent nerves, but differing from $H$. nitida, and in fact from all the other species of which the flowers are known, in the greater length of the calyx lobes, which are nearly as long as the corolla tube, and 
from $H$. nitida in particular in the ferrugineous-tomentellous inflorescence.

It is not impossible that part of the specimens that have been identified with $H$. verticillata (Froés 21518 et 22784 , both from the Rio Negro, Ducke 81, 21683 et 22813, all three from Manaos) will prove to belong to a nearly. related, but as yet undescribed species. The leaves of these plants are 4-nate, wider and with a rounded instead of acute base, and provided with a smaller number of nerve pairs (7-9 instead of 11), and the corolla is slightly larger (tube $3 \mathrm{~cm}$ long instead of $2.3 \mathrm{~cm}$ ). However, more material, preferably from the type locality, will have to be compared, before it will be possible to decide whether these differences fall outside the normal range of variability.

My new species offers in this respect no difficulties; the points in which it differs from its allies are numerous and well-marked. Nor can it be doubted that it belongs to the Henriqueziaceae; this follows from the presence of the "gland "at the base of the petiole, its slightly zygomorphous corolla with the streak of hairs running down the ventral side of the campanulate throat, the five stamens inserted at unequal height and provided with filaments showing a bent at the base; that it belongs to Henriquezia follows from the number and shape of the stipules and their insertion on the basal part of the petiole, the comparatively large size of the corolla, the 5-colpate pollen grains, and the presence of 3 or 4 ovules in each of the ovary cells.

Henriquezia longisepala Brem. n. spec. stipulis persistentibus cum $H$. macrophylla Ducke, $H$. Fenmanii $\mathrm{K}$. Sch. et $H$. nitida Spruce ex Bth., foliis ternatis cum $H$. oblonga Spruce ex Bth., $H$. Jenmanii et $H$. nitida, nervis non prominentibus cum $H$. oblonga et $H$. nitida congruens, a $H$. macrophylla foliis ternatis, multo minoribus et nervis non prominentibus instructis, a $H$. Jenmanii nervis non prominentibus et foliis insuper apice rotundatis, a $H$. nitida inflorescentia ferrugineotomentella, a $H$. oblonga stipulis persistentibus et foliis multo minoribus distinguenda, a speciebus omnibus quarum calyx hactenus notus est, insuper longitudine sepalorum diversa.

Arbor parva, circ. $4 \mathrm{~m}$ alta. Ramuli novelli obtuse triangulares, ferrugineo-tomentelli, 4-5 mm diam., internodiis $1.0-4.5 \mathrm{~cm}$ longis; ramuli veteriores cortice griseo-brunneo opaco vestiti. Folia ternata; petiolus glandula basali excepta ferrugineo-tomentellus $1.5-1.7 \mathrm{~cm}$ longus; lamina oblonga vel oblongo-oblanceolata, $12-18 \mathrm{~cm}$ longa et $4.5-7.0 \mathrm{~cm}$ lata, apice rotundata et mucronulata, basi acuta et in petiolum decurrens, coriacea, utrimque glabra, supra in foliis maturis nitida, sicc. chryseo-lutea, subtus pallidior, costa supra latitudine conspicua, prominula, longitudinaliter striata, subtus prominente, nervis utroque latere costae plerumque 12 , utrimque distinguendis sed non prominentibus, inter nervos supra sub lente reticulata, subtus laevis. Stipulae circ. $2 \mathrm{~cm}$ longae, acutissime exeuntes, marginibus incurvatae, persistentes. Inflorescentia pedunculo ferrugineo-tomentello $4 \mathrm{~cm}$ longo instructa; rachis $3 \mathrm{~cm}$ longa, etiam ferrugineotomentella. Bracteae ramulos suffulcientes circ. $15 \mathrm{~mm}$ longae et $4 \mathrm{~mm}$ latae, infimae 3-fidae, aliae integrae, ad anthesin deciduae. 
Flores pedicello ferrugineo-tomentello circ. $8 \mathrm{~mm}$ longo elati. Ovarium ferrugineo-tomentellum $4 \mathrm{~mm}$ altum, utroque loculo ovulis 3 vel 4 instructo. Calycis lobi lineari-lanceolati, $2.5-3.0 \mathrm{~cm}$ longi, tertia parte inferiore circ. $3 \mathrm{~mm}$ lati, costati, ad medium $6.5 \mathrm{~mm}$ lati, tertia parte superiore sensim attenuati, extus ferrugineo-tomentelli, intus griseo-tomentosi. Corolla miniata, extus griseo-tomentosa, tubo campanulato $3.0 \mathrm{~cm}$ longo et parte superiore $1.5 \mathrm{~cm}$ diam., lobis circ. $1.3 \mathrm{~cm}$ longis et $0.9 \mathrm{~cm}$ latis. Stamina filamentis glabris 11 et $13 \mathrm{~mm}$ longis et antheris $7 \mathrm{~mm}$ longis instructa. Granula pollinis depresse globosa, 5-angularia et 5-colpata, $75 \mu$ diam. Discus tomentellus. Stylus glaber $22 \mathrm{~mm}$ longus; stigmata 2 linearia $1 \mathrm{~mm}$ longa. Capsula nondum visa.

Habitat Amazoniam Brasiliensem.

Brazil: Amazonas; Rio Negro, São Felipe, Igara pé Touri, Froés 28781, 27 Sept. 1952 (ex Inst. Agron. do Norte), type (U).

The studies on which this paper is based, were made possible by a grant from the "Netherlands Organization for Pure Research (Z.W.O.)". 